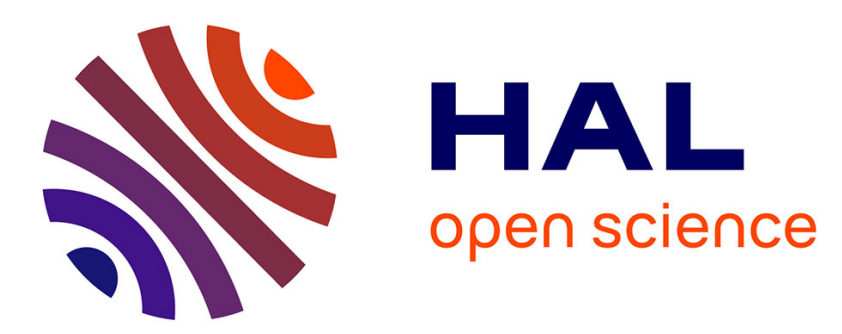

\title{
Effects of shock loading on cobalt-based solid-solution strengthened superalloys
}

\author{
K. Vecchio, A. Thakur
}

\section{To cite this version:}

K. Vecchio, A. Thakur. Effects of shock loading on cobalt-based solid-solution strengthened superalloys. Journal de Physique IV Proceedings, 1994, 04 (C8), pp.C8-367-C8-372. 10.1051/jp4:1994856 . jpa-00253416

\section{HAL Id: jpa-00253416 https://hal.science/jpa-00253416}

Submitted on 1 Jan 1994

HAL is a multi-disciplinary open access archive for the deposit and dissemination of scientific research documents, whether they are published or not. The documents may come from teaching and research institutions in France or abroad, or from public or private research centers.
L'archive ouverte pluridisciplinaire HAL, est destinée au dépôt et à la diffusion de documents scientifiques de niveau recherche, publiés ou non, émanant des établissements d'enseignement et de recherche français ou étrangers, des laboratoires publics ou privés. 


\title{
Effects of shock Ioading on cobalt-based solid-solution strengthened superalloys
}

\author{
K.S. Vecchio and A.M. Thakur
}

Dept. of Applied Mechanics and Engineering Sciences, University of CA, San Diego, LaJolla, CA 92093, U.S.A.

\begin{abstract}
Resumé
Les alliages HAYNES $25^{\mathrm{TM}}$ et $188^{\mathrm{TM}}$ on été étudiés pour déterminer l'effet du chargement par choc sur la réponse mécanique et l'évolution de microstructure sous rechargements quasi-statique et dynamique. Les propriétés sous compression ont été étudiées pour ces matériaux à leur état inital ainsi qu'à l'état prédeformépar choc. Les vitesses de déformation en compression varient de $10^{-3} / \mathrm{s}$ à $3000 / \mathrm{s}$ et les températures de déformation sont $77^{\circ} \mathrm{K}$ et $293^{\circ} \mathrm{K}$. Des traitement de recuit à des températures variant de $300^{\circ} \mathrm{C}$ à $800^{\circ} \mathrm{C}$ ont suivi le chargment par choc. Pour des températures de recuit en dessous de $600^{\circ} \mathrm{C}$, la résistance à l'écoulement plastic sous rechargement et les vitesses d'écrouissage augmentent par rapport aux conditions de choc. L'adoucissement expecté n'à été observé qu'à des températures en dessus de $600^{\circ} \mathrm{C}$. Les changements de microstructure, responsables des differences dans les propriétés mécaniques, ont été documentés par l'utilisation du microscope éléctronique à transmission.
\end{abstract}

\begin{abstract}
Co-based HAYNES ${ }^{\circledR} 25^{\mathrm{TM}}$ and $188^{\mathrm{TM}}$ alloys have been studied to determine the effect of shockloading on the post-shock quasi-static and dynamic mechanical response, and microstructural evolution. The compression properties of these materials were studied in both the as-received and shock-loaded conditions at strain rates from $10^{-3} / \mathrm{s}$ to $3000 / \mathrm{s}$, and 77 and $293 \mathrm{~K}$. Isochronal annealing treatments were conducted at temperatures ranging from 300 to $800^{\circ} \mathrm{C}$, following the shock-loading. For annealing temperatures below $600^{\circ} \mathrm{C}$, the reload yield strengths and strain hardening rates were found to increase relative to the as-shocked condition, and only at temperatures above $600^{\circ} \mathrm{C}$ was the expected softening observed. The microstructural changes responsible for these differences in mechanical properties were documented via TEM.
\end{abstract}

\section{INTRODUCTION}

To date most research on shock-loading effects in FCC materials has been directed at either pure metals or metal alloys strengthened by single element solid solutions or precipitates. Shock-loaded fcc metals and alloys have been repeatedly shown to exhibit increased defect storage, and concurrent higher hardening, behavior in reload tests after shock recovery compared to the same metal deformed at low strain rate to an equivalent strain level [1-3]. By comparison, relatively little work has probed the response of complex alloys which derive their mechanical properties through a combination of strengthening mechanisms.

Solid-solution strengthened superalloys such as: HAYNES alloys 188 and 25 , derive their strength from a combination of solid-solution additions and carbide precipitation, and can be further strengthened by 
cold-working. Shock-loading effects in alloys that exhibit a combination of several strengthening mechanisms and complex microstructures has not been the focus of extensive research to date. However, recent investigations of shock-loading effects in nickel-based superalloys [4], and intermetallics [5] have shown that certain materials exhibit little or no enhanced hardening. The purpose of this study was to investigate the effect of shock-loading on the mechanical properties of $\mathrm{Co}$ based superalloys, and to correlate these properties to the microstructural changes and substructure evolution as a function of strain rate and test temperature. In addition, post-shock annealing treatments were used to investigate the microstructural stability of the shock-loaded materials.

\section{EXPERIMENTAL TECHNIQUES}

Co-based HAYNES ${ }^{\circledR} 25^{\mathrm{TM}}$ and $188^{\mathrm{TM}}$ alloys in the form of hot-rolled bar were obtained from Haynes International, Kokomo, IN to determine the effect of shock-loading on the post-shock quasi-static and dynamic mechanical response, and microstructural evolution. The nominal compositions of both these syperalloys are given in Table 1. Shock recovery experiments were performed at New Mexico Tech., Socorro, NM using shock recovery techniques described elsewhere [6]. Samples were explosively shock-loaded to a shock pressure of $49 \mathrm{GPa}$ for a $1.0 \mu \mathrm{s}$ pulse duration. The pulse duration of $\sim 1 \mu \mathrm{s}$ is defined as: $t_{p}=\frac{2 d_{o}}{U_{s}}$, where $d_{o}$ is the flyer plate thickness and $U_{s}$ is the shock velocity in the flyer plate. Compression samples were EDM machined from the as-received bar stock and shock-recovered samples. The compression properties of these materials were studied in both the as-received and shock-loaded conditions at strain rates from $10^{-3} / \mathrm{s}$ to $3000 / \mathrm{s}$, and 77 and $293 \mathrm{~K}$. The high strain rate tests were conducted on a split-Hopkinson compression bar. Isochronal annealing treatments were conducted at temperatures ranging from 300 to $800^{\circ} \mathrm{C}$, following the shock-loading. Samples for TEM were also sectioned from the recovered samples and observed using a Philips $\mathrm{CM}-30$ operating at $300 \mathrm{kV}$.

TABLE 1

Nominal Chemical Compositions of the Cobalt-based Superalloys

\begin{tabular}{|c|c|c|c|c|c|c|c|c|c|c|}
\hline Material & $\mathrm{Co}$ & $\mathrm{Cr}$ & $\mathrm{W}$ & $\mathrm{Ni}$ & $\mathrm{Fe}$ & $\mathrm{Mn}$ & $\mathrm{Si}$ & $\mathrm{C}$ & $\mathrm{La}$ & $\mathrm{B}$ \\
\hline Alloy 25 & Bal. & 20.0 & 15.0 & 10.0 & 3.0 & 1.50 & 0.40 & 0.10 & $\mathrm{n} / \mathrm{a}$ & $\mathrm{n} / \mathrm{a}$ \\
\hline Alloy 188 & Bal. & 22.0 & 16.0 & 22.0 & 3.0 & 0.50 & 0.35 & 0.10 & 0.07 & 0.015 \\
\hline
\end{tabular}

\section{RESULTS AND DISCUSSION}

Figure 1 shows optical micrographs of the as-received alloys 188 and 25 . The microstructures consists of equiaxed grains, which contain annealing twins and $\mathrm{M}_{6} \mathrm{C}$ carbides. The optical microscopy of the asreceived and the as-shocked conditions did not reveal any significant differences. The presence of the annealing twins in the microstructure is indicative of a FCC matrix having a low stacking fault energy. Deformation twins and microbands were observed as changes in the microstructure of the shock-loaded specimens compared to the as-received condition when examined via the TEM.

The mechanical response of the as-received alloy 25 and alloy 188 at a strain rate of $10^{-3} / \mathrm{s}$ and $3000 / \mathrm{s}$, each at temperature of $293 \mathrm{~K}$ and $77 \mathrm{~K}$ are shown in Figure 2(a) and 2(c). The most striking aspects of these curves is the strong dependence of the yield strength on strain rate and temperature, as well as the apparent dependence of strain hardening rate on strain rate. Figure 2(b) and 2(d) present plots of true stress-true strain response of the shock-loaded alloys 25 and 188. At a fixed temperature and strain rate the flow properties of the shock-loaded alloys are higher than the flow properties of the as-received alloys.

Figure 3 shows the as-received stress-strain response plotted along with the shock-loaded reload curves, with the reload curves offset in strain by the transient strain introduced by the shock. The reload curves for the shock prestrained superalloys in this figure have been offset with respect to the as-received responses at low-strain rate by the transient strain generated by the shock defined as $4 / 3 \ln \left(\mathrm{V} / \mathrm{V}_{\mathrm{O}}\right.$ ), where $\mathrm{V}$ and $\mathrm{V}_{\mathrm{O}}$ are the final and initial volumes of Co during a $49 \mathrm{GPa}$ shock cycle. The volumes utilized in 


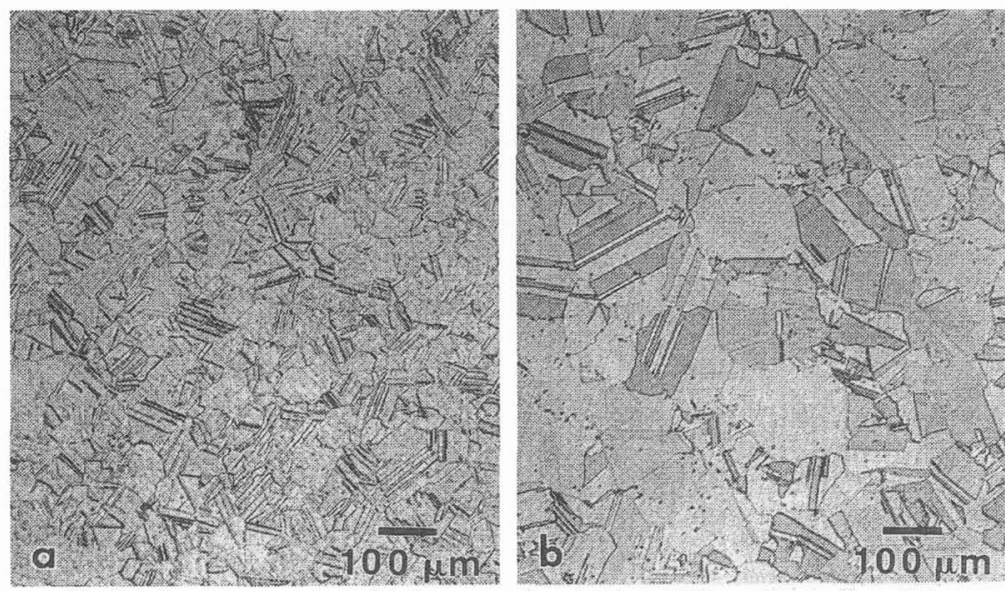

Figure 1. Optical micrographs of (a) as-received alloy 188 and (b) alloy 25.
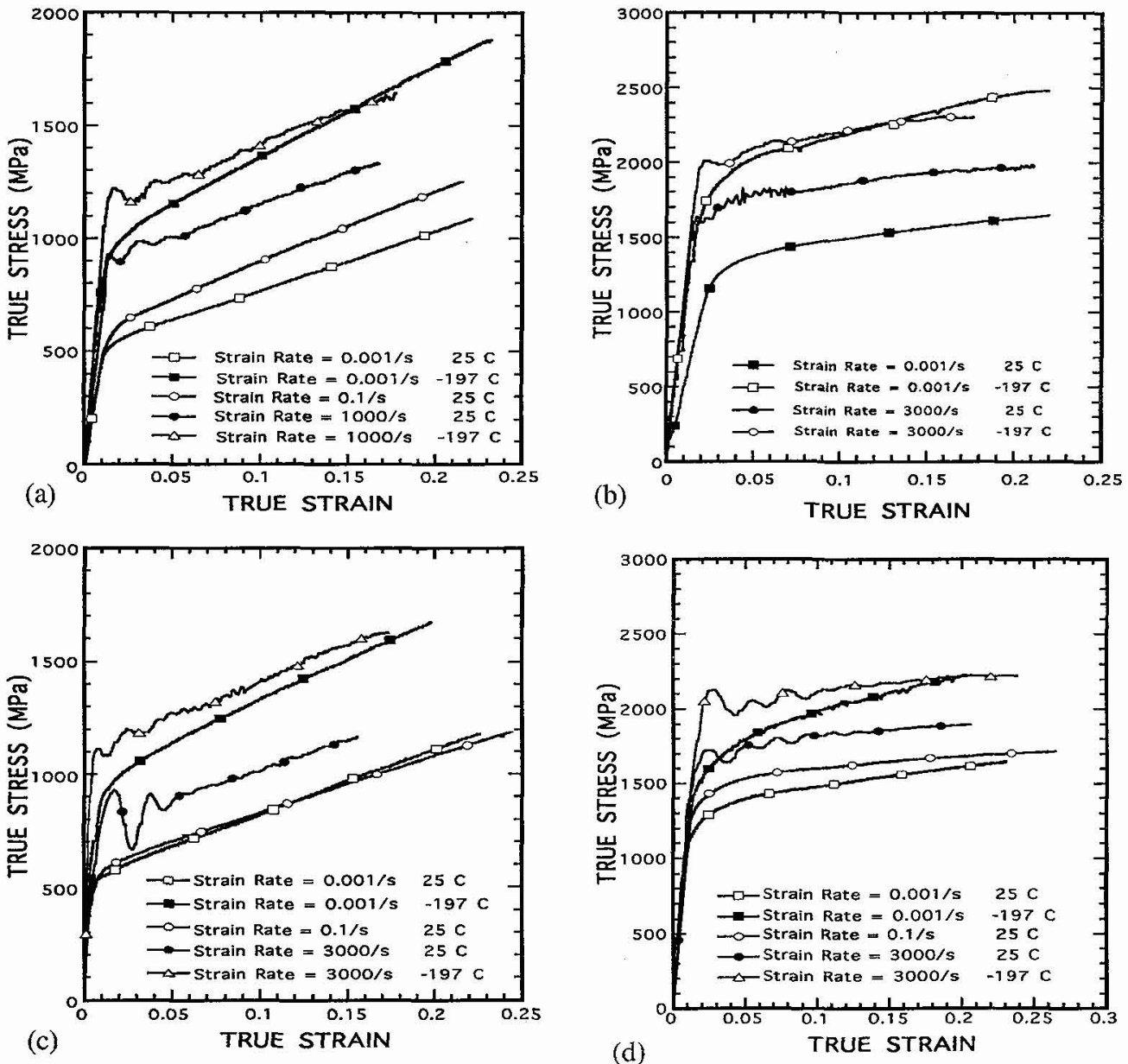

Figure 2. Stress-Strain response as a function of strain rate and temperature for (a) Alloy 25 AsReceived, (b) Alloy 25 Shock-Loaded to $49 \mathrm{GPa}$, (c) Alloy 188 As-Received, and (d) Alloy 188 Shock-Loaded to $49 \mathrm{GPa}$. 

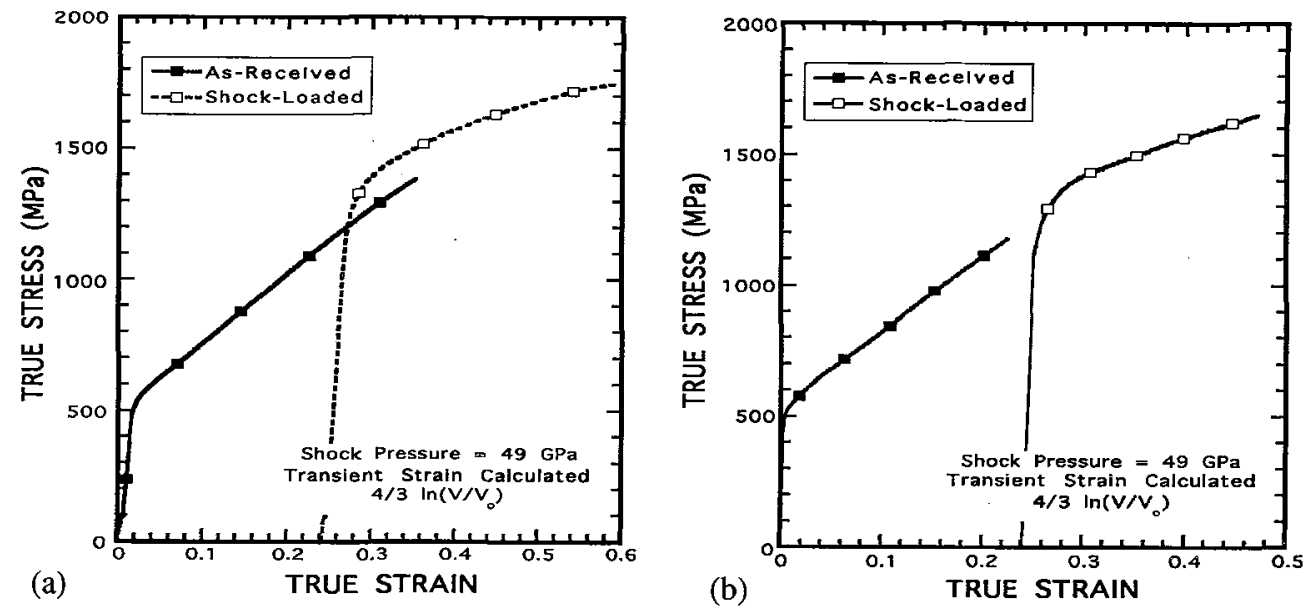

Figure 3. Stress-Strain response comparison between as-received and shock-loaded conditions with the shock-loaded reload curve offset by the calculated transient strain introduced by the shock, (a) alloy 25 and (b) alloy 188 .

this calculation assume the equations of state (EOS) response of pure cobalt for both superalloys since the superalloy's EOS's are unknown. The reload curve for alloy 25 shows a small degree of enhanced hardening compared to the level achieved through quasi-static deformation; whereas the reload curve for alloy 188 shows almost no enhanced hardening.

Specimens of shock-loaded alloys 25 and 188 were annealed for one hour at different temperatures ranging from $300^{\circ} \mathrm{C}$ to $800^{\circ} \mathrm{C}$. The room temperature mechanical response of these shock loaded-andannealed materials were tested at a strain rate of $10^{-3} / \mathrm{s}$ and the reload curves are shown in Figure 4. Low temperature annealing (e.g. $400^{\circ} \mathrm{C}$ or $500^{\circ} \mathrm{C}$ ) of the shock-loaded microstructures harden the alloys beyond the as-shocked condition as indicated through an increase in the flow curves for these temperatures. At 700 and $800^{\circ} \mathrm{C}$, the flow stresses fall below the as-shocked curves as expected from typical annealing treatments. The increase in flow stress with the low temperature anneals is in contrast to what might be expected from conventional annealing effects. To determine whether this effect is due to a "strain-aging" effect or alternatively a "shock" effect, additional specimens of as-received materials were quasi-statically deformed to strains approximately equivalent to the transient shock strains, subsequently aged at either 400 or $500^{\circ} \mathrm{C}$, and reloaded quasi-statically. Figure 5 shows the results of these tests, which indicate that these reload curves do not increase in strength following aging, and in the case of alloy 25 shows a clear strength loss.

If a "strain-aging" effect were responsible for the observations in Figure 4, then the reload curves in Figure 5 should have also increased following these annealing treatments. Evidently, other microstructural changes must occur as a result of the shock-loading and annealing; these changes were investigated via the TEM. Figure 6 shows TEM micrographs of alloy 25 specimens shock-loaded + annealed at $400^{\circ} \mathrm{C}$ (Figure 6(a)), and $700^{\circ} \mathrm{C}$ (Figure 6(b)). After annealing at $400^{\circ} \mathrm{C}$, numerous finely spaced twins appear in the microstructure; similar observations were made at the annealing temperatures of 500 and $600^{\circ} \mathrm{C}$, and for alloy 188 as well. The number of these twins was clearly increased over the as-shocked conditions, however the dislocation density appeared unchanged. The finely spaced twins introduced by the low temperature anneals act effectively as grain boundaries, which results in increased strength (i.e. grain refinement), while at the same time maintaining the as-shocked work hardening rates. Following the 700 or $800^{\circ} \mathrm{C}$ annealing treatments, the twin and dislocation density was significantly reduced, resulting in the observed strength loss, but the increased rate of work hardening. 


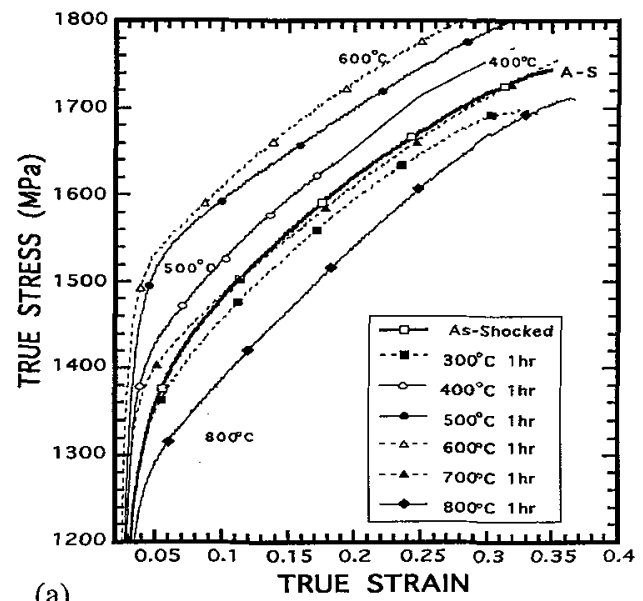

(a)

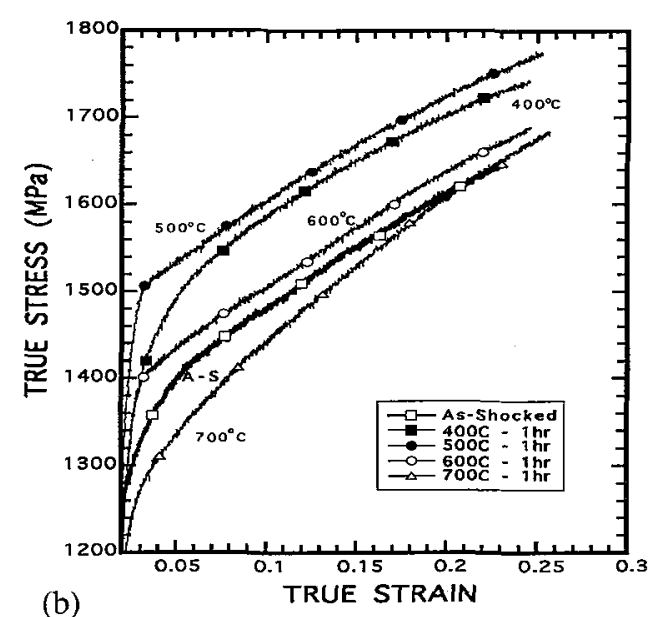

(b)

Figure 4. Stress-Strain response of shock-loaded materials followed by 1 hour annealing at different temperatures between $300^{\circ} \mathrm{C}$ and $800^{\circ} \mathrm{C}$ (a) alloy 25 and (b) alloy 188 . Note the increase in strength for the annealing temperatures below $700^{\circ} \mathrm{C}$, compared to the as-shocked condition. The stress-strain data has been presented only from a true strain of 0.02 so as to allow expansion of the stress data around the yield region.

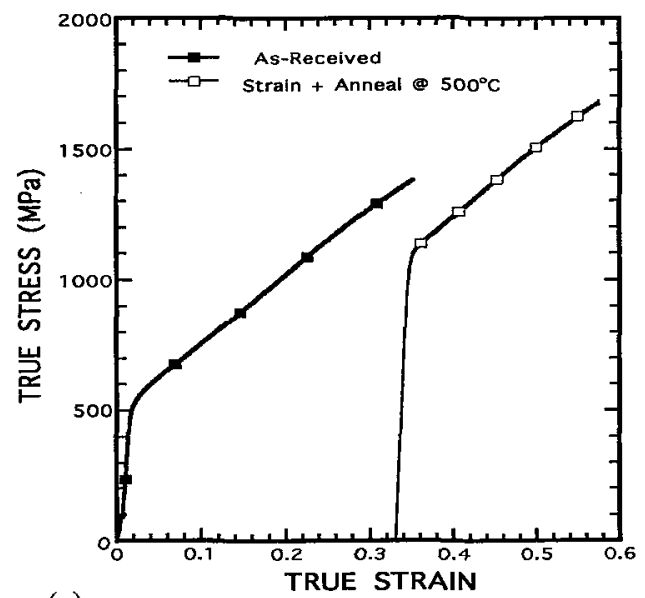

(a)

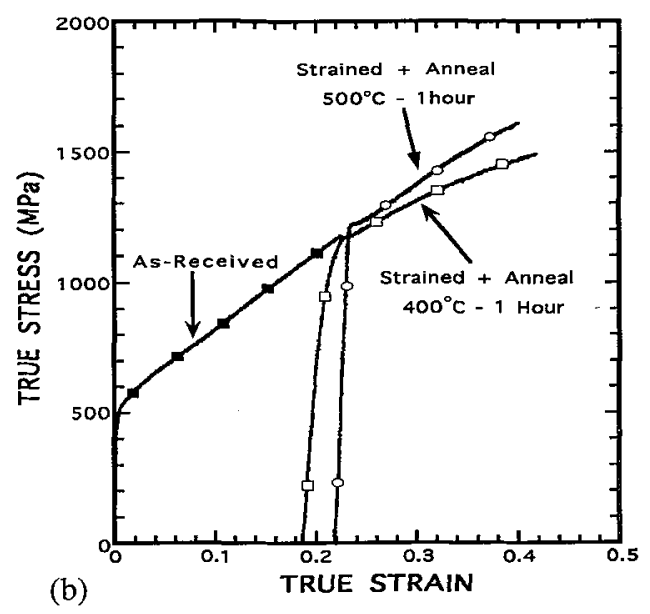

(b)

Figure 5. Stress-Strain response of as-received materials quasi-statically deformed to a strain approximately equal to the strain introduced during shock loading, followed by annealing for 1 hour at 400 or $500^{\circ} \mathrm{C}$. Note that this annealing treatment does not result in increased strength compared to the strength of the quasi-statically deformed as-received materials, (a) alloy 25 and (b) alloy 188.

\section{SUMMARY AND CONCLUSIONS}

Co-based superalloys, HAYNES 25 and 188, have been studied to determine the effects of shockprestraining on the reload stress-strain response of these materials. It has been shown that shock-loading results in only a minor increase in strength in alloy 25 , compared to that achieved by quasi-static deformation, and essentially no enhanced strengthening in alloy 188. Shock-prestraining does however reduce the rate of hardening in both alloys compared to quasi-static hardening rates. Isochronal 
annealing treatments were conducted at temperatures ranging from 300 to $800^{\circ} \mathrm{C}$, following the shockloading. For annealing temperatures below $600^{\circ} \mathrm{C}$, the reload yield strengths were found to increase relative to the as-shocked condition, and only at temperatures above $600^{\circ} \mathrm{C}$ was the expected softening and concurrent increase in hardening rates observed. The microstructural changes responsible for these differences in mechanical properties were documented via TEM, and showed that the increase in strength was attributable to fine scaling twinning introduced by the combination of shock-prestraining and subsequent low temperature annealing.

(a)
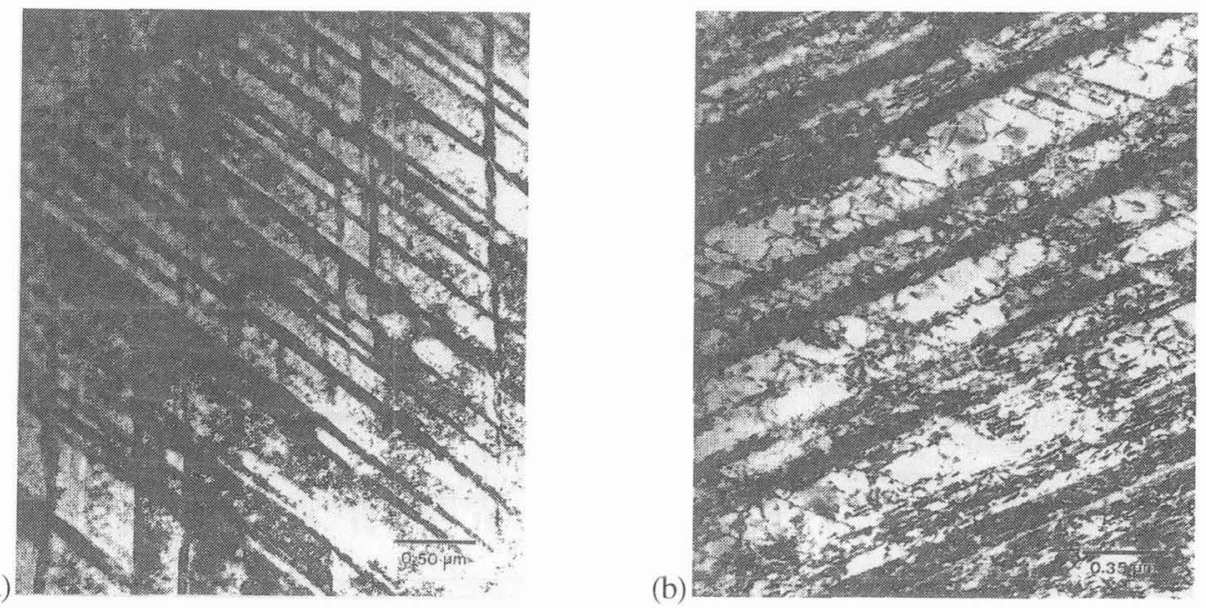

Figure 6. TEM micrographs of alloy 25 following shock-loading and annealing at (a) $400^{\circ} \mathrm{C}$ and (b) $700^{\circ} \mathrm{C}$.

\section{ACKNOWLEDGMENTS}

The authors acknowledge the support of the Army Research Office through a URI grant \# ARO-DAAL03-92-G-0108 for this research, and thank HAYNES International for the donation of materials.

\section{REFERENCES}

[1] G.E. Dieter, in Response of Metals to High Velocity Deformation, Interscience Publishers, New York, pp. 409-445 (1961).

[2] L.E. Murr, in Shock Waves and High Strain Rate Phenomena in Metals, (ed. by M.A. Meyers and L.E. Murr) Plenum Press, N.Y., p. 607 (1981).

[3] Gray III, G.T., High Pressure Shock Compression of Solids (Springer-Verlag, N.Y., N.Y., 1993) 187-215.

[4] Vecchio, K.S. and Gray III, G.T., "Effects of Shock Loading on Solid-Solution Strengthened Superalloys," APS Topical Conference on Condensed Matter-1993 (North-Holland Press, N.Y., 1994) in press.

[5] Gray III, G. T., Influence Of Shock Loading On The Structure / Property Response Of Ti-48Al$2 \mathrm{Cr}-2 \mathrm{Nb}$ and $\mathrm{Ti}-24 \mathrm{Al}-11 \mathrm{Nb}$, to appear elsewhere in this volume.

[6] Meyers, M. A., L. W. Meyer, K. S. Vecchio, and U. Andrade, "High Strain, High Strain-Rate Deformation of Copper," Journal De Physique IV, Colloque C3, suppl. au Journal de Physique III, Oct. 1991, 1, pp. 11-17. 